\title{
The Long Run Effects of Foreign Aid on Economic Growth by Sector of Distribution
}

\author{
Nicholas Larsen \\ Eastern Washington University
}

In this paper we explore the long run effects of a country's economic growth for a panel of 69 developing countries for the period 2002 to 2017. The results suggest that the foreign aid that is given towards social infrastructure has a statistically significant "multiplier effect" where an increase in foreign aid by approximately $\$ 48$ will increase economic growth by $1 \%$. Foreign aid given towards social infrastructure includes money being spent on all levels of education which could further emphasize the importance of education for long run economic growth. Foreign aid given towards economic infrastructure or production sectors is either not statistically significant or has a negative correlation.

Keywords: economic growth, foreign aid, long-run impact

\section{INTRODUCTION}

The effectiveness of foreign aid has been a controversial topic and has been extensively researched, while remaining theoretically ambiguous for the last half century (Burnside and Dollar 2000). Not only does the efficacy of foreign aid appear to be theoretically ambiguous, but the empirical results have also been inconsistent. The goals of foreign aid may vary by donner - providing for basic infrastructure, meeting agricultural needs, promoting economic growth, poverty reduction, and meeting sanitation and health needs (Temple 2010). The various types of aid have several examples of being successful in eradicating or controlling various diseases (smallpox, polio, and African river blindness) in developing countries (Sachs 2005). But the overall impact on economic growth has remained inconsistent with more than $\$ 2.3$ trillion in foreign aid being given to developing countries over the last half century (Easterly 2006), but more than 1.1 billion people remaining in extreme poverty by the start of this century (Sachs 2005). Some recent research has focused on the type of foreign aid mattering for the expected outcome (Batbold 2017).

Several papers have found that the efficacy of foreign aid on economic growth has had conflicting results. Boone (1996), Brautigam and Knack (2004), and Obstfield (1999) have found evidence of a negative relationship between foreign aid and economic growth while papers like Papanek (1973), Dowling and Himenz (1982), Gupta and Islam (1983), Hansen and Tarp (2000), and Dalgaard et al. (2004) have found evidence that the relationship is positive. The exists some evidence that the effect is not only positive but might also be permanent (Karras 2006 and Larsen 2020). Other evidence has shown that economic conditions within the recipient country are important in determining foreign aids efficacy (Burnside and Dollar 2000), or perhaps they do not matter (Easterly et al. 2004). Or perhaps it is the size of the foreign aid that is received that makes a difference (Sachs 2004, Larsen 2016a and 2016b) under assumptions of the presence of poverty traps. 
This paper will follow the methodology of Karras (2006) — which is based on Jones (1995) — which analyzes the efficacy of foreign aid using a panel dataset instead of the dominant literature that uses only cross-sectional analysis. This allows for a time dimension to be included in the analysis to determine if there are any long run impacts of foreign aid on economic growth. Karras (2006) suggest that the reliance on cross-sectional analysis could be one of the factors that has led to many papers finding conflicting results. This paper will extend the analysis of Karras (2006) by analyzing the long run impact of foreign aid by the type of aid that is received, not just looking at only Official Development Aid. Because of data limitations for when total aid is disaggregated by type this analysis is limited to four-year data from 2002-2017 for 69 developing countries that reported data for all variables during this period.

This paper not only finds results that are both economically and statistically significant, but also that vary depending on the type of foreign aid that is received. The results suggest that the effect of foreign aid on per capita economic growth can be positive, but only if the aid is being funneled into the right areas. The results suggest that if policy makers would want to target a $1 \%$ permanent increase in per capita economic growth than they should increase the per capita foreign aid given to social infrastructure by $\$ 48.19$. This positive result is like the result found in Larsen (2020), with the difference being that targeting only the social infrastructure needs less than half of the amount to get a $1 \%$ growth compared to total official development aid. It appears that the other avenues for foreign aid have either smaller, or even negative correlations with economic growth.

The rest of the paper is organized as follows. In section 2 the data is defined, and a simple crosssectional regression is presented for comparison to some previous studies and to illustrate the limitations a cross-sectional methodology. In section 3 the main empirical model that is used is discussed and the results are presented. Section 4 discusses some potential policy implications and the conclusions of the paper.

\section{DATA}

The data consists of a panel of 69 countries that received foreign aid, from 2002-2017 obtained from the Penn World Table 9.1 (Feenstra et. al 2015). For data that is reported in current dollars an implied GDP deflator is created using the PWT measures for current and constant GDP to translate current variables into constant 2010 dollars. The descriptive statistics for the variables can be found in the appendix along with a table disaggregating the type of foreign aid in a more granular level. The dependent and independent variables are defined as follows.

Dependent Variable:

1. Growth: $\left(\ln (\mathrm{GDP} / \mathrm{N})_{\mathrm{i}, \mathrm{t}}-\ln (\mathrm{GDP} / \mathrm{N})_{\mathrm{i}, \mathrm{t}-\mathrm{4}}\right) / 4$

2. Level: $\left(\ln (\mathrm{GDP} / \mathrm{N})_{\mathrm{i}, \mathrm{t}}\right)$

Explanatory Variables for a "standard" neoclassical growth model:

1. Natural log of initial year GDP/N.

1. Natural log of average percent of investment to GDP by period (Ln I).

2. Natural log of average percent of government expenditure to GDP by period ( $\operatorname{Ln}$ G).

3. Natural log of average human capital index (Ln HC).

- Based on years of schooling and returns to education.

- Described in "Human Capital" in PWT 9.

4. Natural log of population growth (Ln Pop)

- Population growth is the averaged growth rate of the population by period.

Measures of Foreign Aid considered: A summary of the sectors is found in Table 2 of the appendix.

5. Natural log of average percentage of foreign aid per Gross Domestic Product (GDP) a country receives over the period.

- Measured as either the nominal: Total, Social Infrastructure and Services, Economic Infrastructure and Services, or Production Sectors over the nominal GDP averaged over the period.

- Foreign aid is from oecdstat at www.oecd.org 
6. Natural log of average percentage of foreign aid per capita a country receives over the period.

- Measured as the real Total, Social Infrastructure and Services, Economic Infrastructure and Services, or Production Sectors per capita averaged over the period.

- ODA is from oecdstat at www.oecd.org.

\section{FIGURE 1 \\ AVERAGE TOTAL GDP RECEIVED AND PER CAPITA ECONOMIC GROWTH, AVERAGED 69 COUNTRIES}

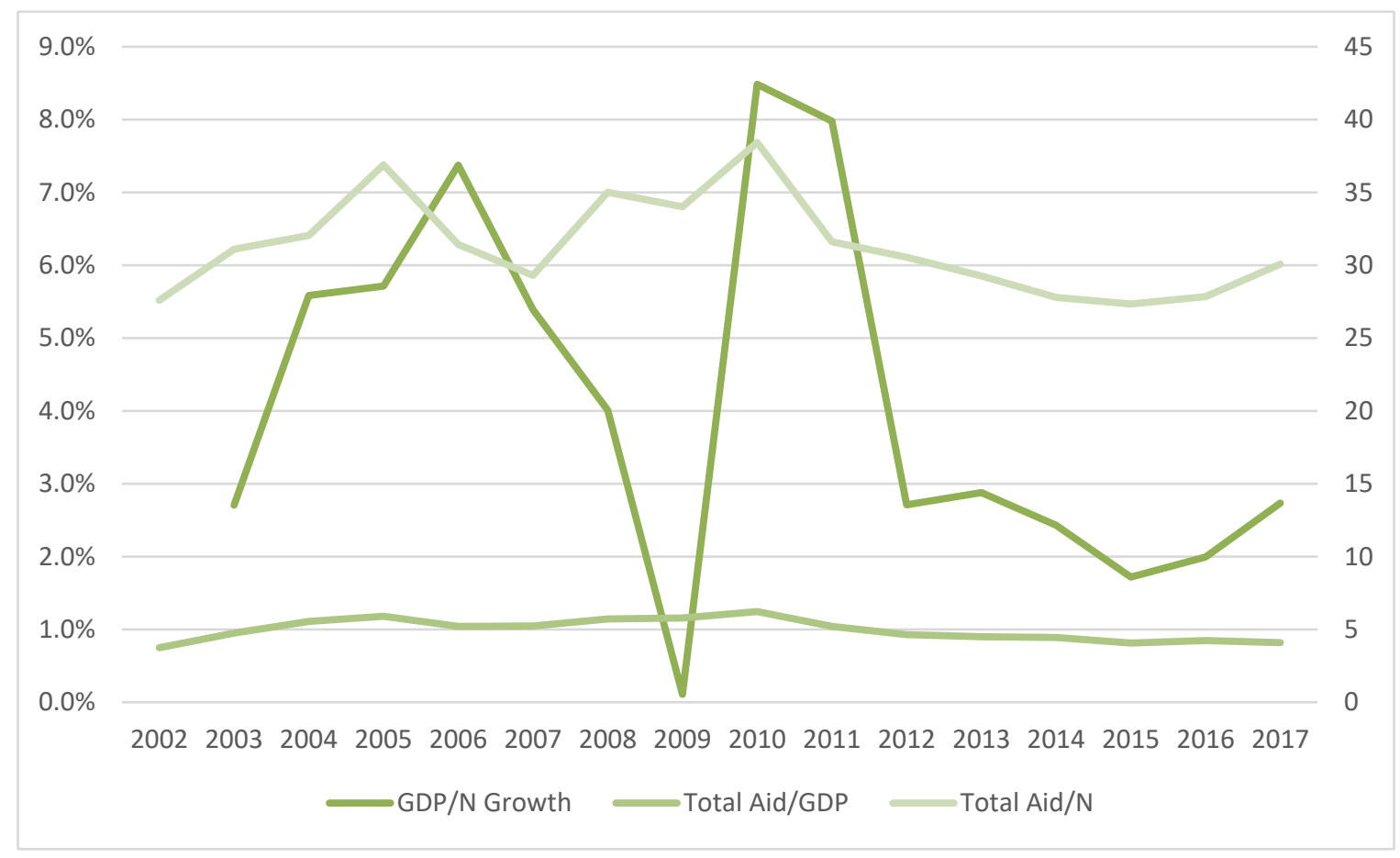

The trends of total foreign aid as a percentage of GDP and per capita along with per capita economic growth are presented in Figure 1 averaged for the 69 recipient countries used in this study. The 2009 global recession can be clearly seen in the figure, with the average economic growth for the countries plummeting. Additionally, we see that the amount of foreign aid that the countries received ticked up following the recession before coming back down a few years later. Over the period in this study the amount of per capita the amount of foreign aid that a recipient country received averaged between approximately $\$ 27$ to almost $\$ 40$. When measuring the foreign aid that was received as a percentage of GDP the fluctuations appear to be less volatile and stay around 1\% the entire period. In Figure 2 we observe the relative size of the foreign aid averaged by type for the 69 recipient countries for the period. Social infrastructure foreign aid is the largest category of foreign aid at about $50 \%$ of the total amount. Economic and productivity infrastructure combined are about $2 / 3$ the size of social infrastructure. In the start of the period economic and productivity infrastructure were similar in magnitude, but as time went on the amount of money received for economic infrastructure started to trend upward while the productivity infrastructure remained steady.

Social infrastructure and services go towards expenditures in education-basic, secondary, and postsecondary-health, along with other services. The economic infrastructure includes money spent in areas like transportation, communications, energy, etc. While production sectors include agriculture, forestry, industry, etc. A full break down of the infrastructure and services that fall under these three categories can be found in Table 2 of the appendix. Looking at the breakdown of infrastructure and services in each of these categories the social infrastructure's human capital expenditures have the clearest connection with a neoclassical economic growth model. 
FIGURE 2

RELATIVE SIZE OF FOREIGN AID BY TYPE, AVERAGED BY 69 COUNTRIES

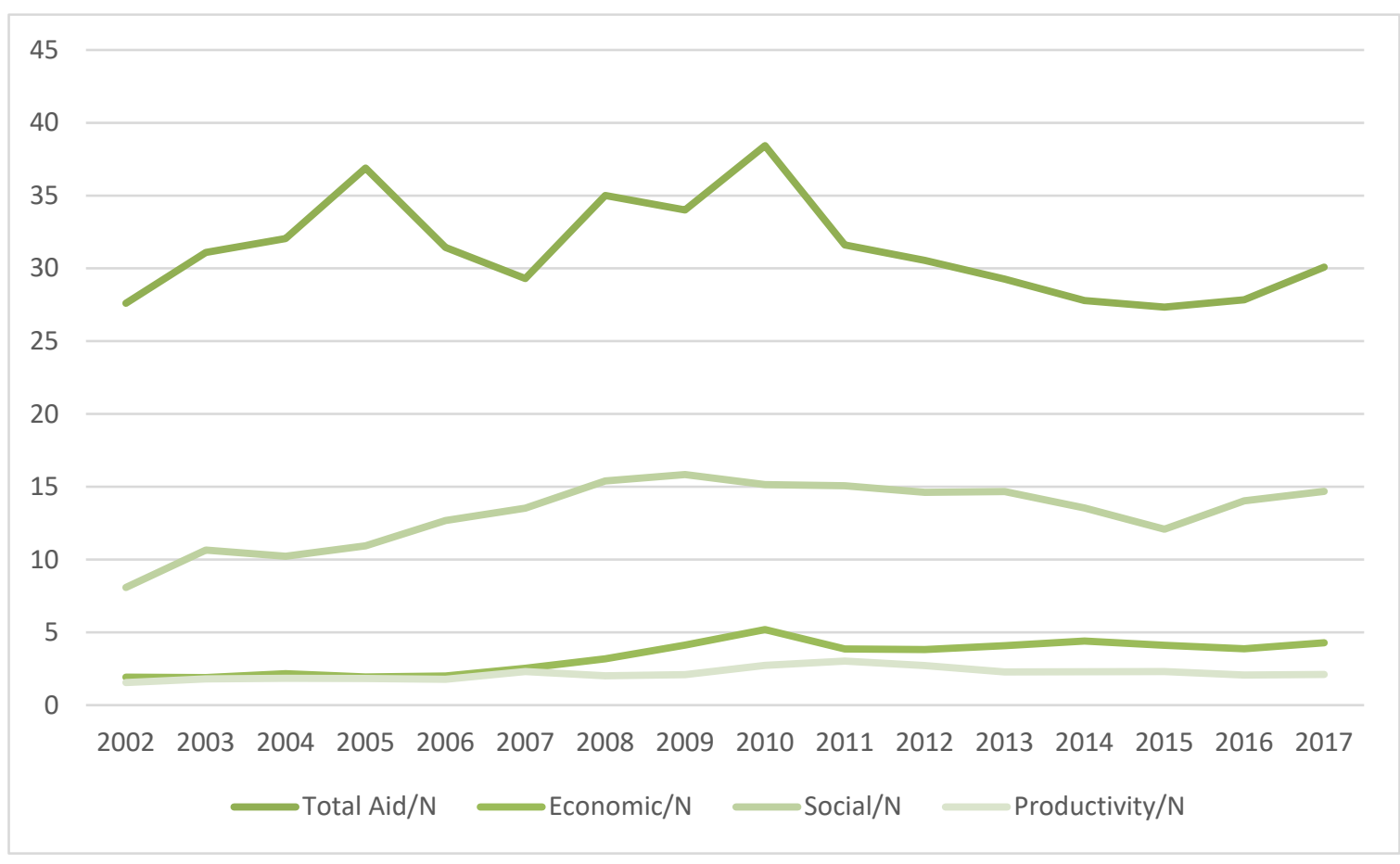

From the cross-sectional regressions presented in Tables 1 and 2 we find results that are consistent with standard neoclassical growth models found in Mankiw et al. (1992). In Table 1 we report the regression for the level of income per capita. The variables are not statistically significant in every specification of the models, but they are all consistent with most of the neoclassical literature. We are finding that human capital and investment have a positive correlation the level of per capita income, while the population growth has negative correlation. Most of the significant foreign aid variables appear to be negative apart from the economic infrastructure aid variable which is positive.

Table 2 presents the cross-sectional regression for per capita economic growth. Like the level of income regressions, the economic growth regressions are also consistent with much of the neoclassical literature. The negative coefficient on the initial GDP per capita variable is evidence of conditional convergencepoorer countries are growing faster to "catch-up" with the richer countries conditional on the other variables in the regression. We are still observing a positive coefficient for human capital accumulation and the level of investment in the country. The other variables are not appearing to be statistically significant in these specifications. We are again only finding a positive correlation between aid given to economic infrastructure while the other categories appear to be negative or not statistically significant. 
TABLE 1

CROSS-SECTIONAL REGRESSION FOR PER CAPITA LEVEL OF INCOME

\begin{tabular}{|c|c|c|c|c|c|}
\hline $\begin{array}{l}\text { Dependent: } \\
\text { Level }\end{array}$ & (1) & (2) & (3) & (4) & (5) \\
\hline $\operatorname{lnHC}$ & $\begin{array}{c}2.3219 * * * \\
(0.3198)\end{array}$ & $\begin{array}{c}2.2900 * * * \\
(0.3118)\end{array}$ & $\begin{array}{c}2.1625^{* * *} \\
(0.2974)\end{array}$ & $\begin{array}{c}1.5719 * * * \\
(0.2667)\end{array}$ & $\begin{array}{c}1.6795 * * * \\
(0.2611)\end{array}$ \\
\hline $\operatorname{lnPop}$ & $\begin{array}{c}-0.2774 * * \\
(0.1153)\end{array}$ & $\begin{array}{l}-0.2148^{*} \\
(0.1161)\end{array}$ & $\begin{array}{l}-0.1478 \\
(0.1136)\end{array}$ & $\begin{array}{l}-0.0816 \\
(0.0922)\end{array}$ & $\begin{array}{l}-0.0881 \\
(0.0944)\end{array}$ \\
\hline $\operatorname{lnI}$ & $\begin{array}{c}0.6163^{* * *} \\
(0.2080)\end{array}$ & $\begin{array}{c}0.6170 * * * \\
(0.2026)\end{array}$ & $\begin{array}{c}0.4312^{* *} \\
(0.2003)\end{array}$ & $\begin{array}{c}0.4664 * * * \\
(0.1598)\end{array}$ & $\begin{array}{c}0.4227 * * \\
(0.1646)\end{array}$ \\
\hline $\ln G$ & $\begin{array}{c}0.1800 \\
(0.1603)\end{array}$ & $\begin{array}{c}0.2264 \\
(0.1576)\end{array}$ & $\begin{array}{c}0.2044 \\
(0.1488)\end{array}$ & $\begin{array}{l}0.2111 * \\
(0.1221)\end{array}$ & $\begin{array}{l}0.2116^{*} \\
(0.1225)\end{array}$ \\
\hline $\operatorname{lnEconAid/N}$ & & & $\begin{array}{c}0.2523 * * * \\
(0.0835)\end{array}$ & & \\
\hline $\operatorname{lnSocialAid/N}$ & & & $\begin{array}{l}-0.1103 \\
(0.1110)\end{array}$ & & \\
\hline $\ln$ ProdAid/N & & & $\begin{array}{c}-0.2197 * * \\
(0.1066)\end{array}$ & & \\
\hline $\operatorname{lnTotalAid/N}$ & & $\begin{array}{c}-0.1556^{* *} \\
(0.0736)\end{array}$ & & & \\
\hline lnTotalAid/GDP & & & & $\begin{array}{c}-0.3132 * * * \\
(0.0455)\end{array}$ & \\
\hline lneEonAid/GDP & & & & & $\begin{array}{c}0.1055 \\
(0.0712)\end{array}$ \\
\hline lnSocialAid/GDP & & & & & $\begin{array}{c}-0.2252 * * \\
(0.0904)\end{array}$ \\
\hline lnProdAid/GDP & & & & & $\begin{array}{l}-0.1420 \\
(0.0896)\end{array}$ \\
\hline Constant & $\begin{array}{c}7.1865^{* * * *} \\
(0.6357)\end{array}$ & $\begin{array}{c}8.0333 * * * \\
(0.7374)\end{array}$ & $\begin{array}{c}7.7139 * * * \\
(0.6984)\end{array}$ & $\begin{array}{c}6.6626 * * * \\
(0.4899)\end{array}$ & $\begin{array}{c}6.4099 * * * \\
(0.5762)\end{array}$ \\
\hline Observations & 69 & 69 & 69 & 69 & 69 \\
\hline R-squared & 0.6865 & 0.7073 & 0.7503 & 0.8212 & 0.8279 \\
\hline Adj R-sq & 0.667 & 0.684 & 0.722 & 0.807 & 0.808 \\
\hline
\end{tabular}

Standard errors in parentheses

$* * * \mathrm{p}<0.01, * * \mathrm{p}<0.05,{ }^{*} \mathrm{p}<0.10$

Table 2 presents the cross-sectional regression for per capita economic growth. Like the level of income regressions, the economic growth regressions are also consistent with much of the neoclassical literature. The negative coefficient on the initial GDP per capita variable is evidence of conditional convergencepoorer countries are growing faster to "catch-up" with the richer countries conditional on the other variables in the regression. We are still observing a positive coefficient for human capital accumulation and the level of investment in the country. The other variables are not appearing to be statistically significant in these specifications. We are again only finding a positive correlation between aid given to economic infrastructure while the other categories appear to be negative or not statistically significant. 
TABLE 2

CROSS-SECTIONAL REGRESSION PER CAPITA ECONOMIC GROWTH

\begin{tabular}{|c|c|c|c|c|c|}
\hline $\begin{array}{l}\text { Dependent: } \\
\text { Growth }\end{array}$ & (1) & (2) & (3) & (4) & (5) \\
\hline $\operatorname{lnGDP0}$ & $\begin{array}{l}-0.0088 * \\
(0.0045)\end{array}$ & $\begin{array}{c}-0.0101 * * \\
(0.0045)\end{array}$ & $\begin{array}{c}-0.0129 * * * \\
(0.0043)\end{array}$ & $\begin{array}{c}-0.0187 * * * \\
(0.0050)\end{array}$ & $\begin{array}{c}-0.0189 * * * \\
(0.0047)\end{array}$ \\
\hline $\ln \mathrm{HC}$ & $\begin{array}{l}0.0292 * \\
(0.0148)\end{array}$ & $\begin{array}{c}0.0311^{* *} \\
(0.0146)\end{array}$ & $\begin{array}{c}0.0332 * * \\
(0.0137)\end{array}$ & $\begin{array}{c}0.0311^{* *} \\
(0.0136)\end{array}$ & $\begin{array}{c}0.0337 * * \\
(0.0130)\end{array}$ \\
\hline $\operatorname{lnPop}$ & $\begin{array}{l}-0.0029 \\
(0.0042)\end{array}$ & $\begin{array}{l}-0.0014 \\
(0.0042)\end{array}$ & $\begin{array}{c}0.0010 \\
(0.0041)\end{array}$ & $\begin{array}{l}-0.0005 \\
(0.0039)\end{array}$ & $\begin{array}{c}0.0009 \\
(0.0039)\end{array}$ \\
\hline $\ln I$ & $\begin{array}{c}0.0240 * * * \\
(0.0074)\end{array}$ & $\begin{array}{c}0.0244 * * * \\
(0.0073)\end{array}$ & $\begin{array}{c}0.0189 * * \\
(0.0071)\end{array}$ & $\begin{array}{c}0.0228 * * * \\
(0.0068)\end{array}$ & $\begin{array}{c}0.0192 * * * \\
(0.0067)\end{array}$ \\
\hline $\ln G$ & $\begin{array}{l}-0.0019 \\
(0.0057)\end{array}$ & $\begin{array}{l}-0.0003 \\
(0.0057)\end{array}$ & $\begin{array}{c}0.0002 \\
(0.0054)\end{array}$ & $\begin{array}{c}0.0013 \\
(0.0053)\end{array}$ & $\begin{array}{c}0.0015 \\
(0.0051)\end{array}$ \\
\hline $\operatorname{lnEconAid/N}$ & & & $\begin{array}{c}0.0087 * * * \\
(0.0030)\end{array}$ & & \\
\hline lnSocialAid/N & & & $\begin{array}{l}-0.0061 \\
(0.0039)\end{array}$ & & \\
\hline $\ln \operatorname{ProdAid} / \mathrm{N}$ & & & $\begin{array}{l}-0.0054 \\
(0.0038)\end{array}$ & & \\
\hline $\ln$ TotalAid/N & & $\begin{array}{l}-0.0045^{*} \\
(0.0026)\end{array}$ & & & \\
\hline lnTotalAid/GDP & & & & $\begin{array}{c}-0.0081^{* * *} \\
(0.0023)\end{array}$ & \\
\hline lneEonAid/GDP & & & & & $\begin{array}{c}0.0066 * * \\
(0.0029)\end{array}$ \\
\hline lnSocialAid/GDP & & & & & $\begin{array}{c}-0.0082 * * \\
(0.0037)\end{array}$ \\
\hline lnProdAid/GDP & & & & & $\begin{array}{l}-0.0047 \\
(0.0036)\end{array}$ \\
\hline Constant & $\begin{array}{c}0.1072 * * * \\
(0.0363)\end{array}$ & $\begin{array}{c}0.1402 * * * \\
(0.0405)\end{array}$ & $\begin{array}{c}0.1583 * * * \\
(0.0375)\end{array}$ & $\begin{array}{c}0.1567 * * * \\
(0.0363)\end{array}$ & $\begin{array}{c}0.1617 * * * \\
(0.0345)\end{array}$ \\
\hline Observations & 69 & 69 & 69 & 69 & 69 \\
\hline R-squared & 0.2083 & 0.2444 & 0.3568 & 0.3386 & 0.4230 \\
\hline Adj R-sq & 0.145 & 0.171 & 0.271 & 0.275 & 0.346 \\
\hline
\end{tabular}

Standard errors in parentheses

$* * * \mathrm{p}<0.01, * * \mathrm{p}<0.05,{ }^{*} \mathrm{p}<0.10$

In both tables the signs of the coefficients of foreign aid depends on the category of foreign aid that is being considered. On conclusion that could be drawn is that the positive correlation could imply faster growth while a negative implying spending that could slow down growth. And under these conclusions policy makers could use this to efficiently give money only towards the infrastructures that have a positive return. But reaching such causal conclusions can be dangerous. It is possible that we only observing a case of reverse causality. To get around this possible endogeneity we could employ techniques such as 
instrumental variables, but recall this paper is not meaning to contribute to the cross-sectional literature. These regressions are only included for comparison reasons. In this paper we are following the methodology suggested by Karras (2006) that a time component in the analysis to determine the long run impacts of foreign aid on the level of income and economic growth.

\section{MAIN EMPIRICAL MODEL}

Jones (1995) developed a methodology to analyze the long run permanent impact that investment has on economic growth. Karras (2006) extended this methodology to instead look at the permanent long run impact of foreign aid on economic growth. By forgoing the use of a cross-sectional model and instead using a dynamic time-series model we can incorporate a time dimension into the model and find long run permanent impact of foreign aid on economic growth and the level of income. Following the methodology of Karras (2006) we estimate the following model:

growth $_{i, t}=w_{i}+v_{t}+C(L)$ growth $_{i, t-1}+b^{*} \operatorname{aid}_{i, t}+B(L) \Delta a i d_{i, t}+u_{i, t}$

with $i$ and $t$ being for countries and time respectively. $C(L)$ is a $(p-1)^{\text {th }}$ order lag polynomial. In this model if $\mathrm{B}(1)>0$, then a permanent shock to foreign aid will permanently raise the growth rate.

Depending on which sector of foreign aid we are considering we find results that are consistent with Karras (2006) and Larsen (2020). The coefficient for aid $_{i, t}$ is a parameter that is equal to the sum of coefficients of the $\mathrm{A}(\mathrm{L})$ lag operator polynomial, $\Delta=1-\mathrm{L}$ is the difference operator, and $\mathrm{B}(\mathrm{L})$ is the $(\mathrm{p}-1)^{\mathrm{th}}$ order polynomial. We also include both country and time fixed effects: $w_{i}$ and $v_{t}$, respectively. The model is run both with and without fixed effects. Excluding fixed effects means imposing that all the $w_{i}$ and $v_{t}$ 's are exactly equal to 0 . It is not likely that both the period and country fixed effects are exactly 0 , but these regressions are as a comparison for the model with fixed effects and something not possible with a crosssectional methodology. The country and time fixed effects allow us to capture exogenous movements that are country and time specific. Following Jones (1995) the foreign aid enters the first difference in the specification of the model and will be stationary and uncorrelated with the time trend. In this paper considers both a 1 period (4 year) lag. follows:

The long run "multiplier is constructed using the methodology of Karras (2006) and Jones (1995) as

$l=b_{\text {aid }}\left(\left(1-C(1)_{\text {Growth }}\right)\right.$ 


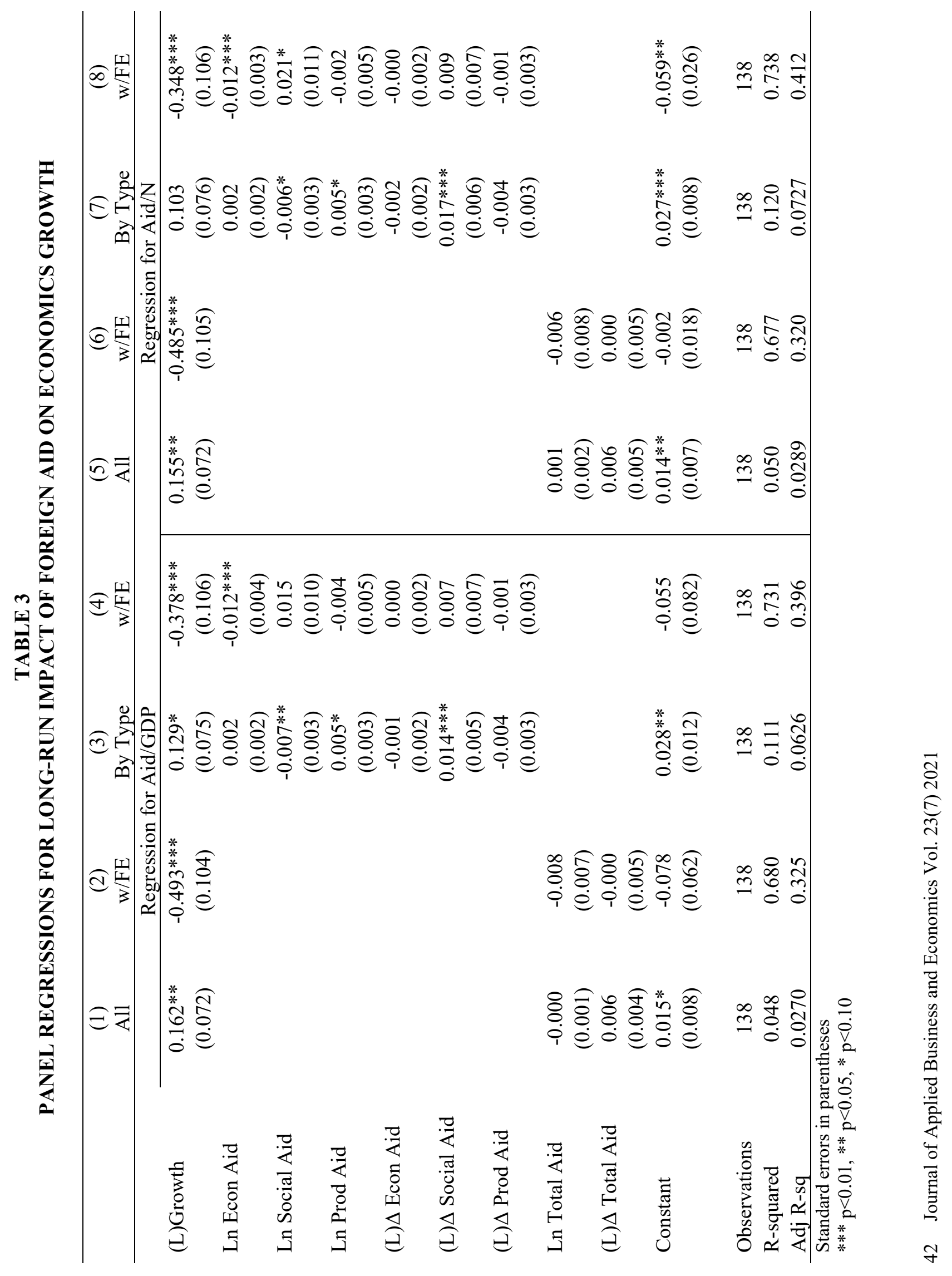


Table 3 presents the time dynamic regressions for total foreign aid or foreign aid for each of the three major sectors measured as either a percentage of GDP or per capita with and without country and time specific fixed effects. Referring to equations 1 and 2 the coefficients of interest are the lag of growth and the coefficient on foreign aid to calculate the "multiplier". One important observation is that the adjusted R-squares are rather poor in the specifications that do not include time and country specific fixed effects. But when the fixed effects are included the fit of the model is significantly improved. In Table 4 we calculate implied multipliers for the permanent impact of foreign aid on per capita economic growth.

\section{TABLE 4 \\ IMPLIED MULTIPLIER FOR PERMANENT IMPACT OF FOREIGN AID ON PER CAPITA ECONOMIC GROWTH}

\begin{tabular}{lcrrr}
\multicolumn{2}{c}{ Aid/GDP } & \multicolumn{2}{c}{ Aid/N } \\
\hline Ln Total Aid & & w/FE $/ \mathrm{FE}$ \\
Ln Econ Aid & 0.0000 & -0.0054 & 0.0012 & -0.0040 \\
Ln Social Aid & 0.0023 & $-0.0087^{* * *}$ & 0.0022 & $-0.0089^{* * *}$ \\
Ln Prod Aid & $-0.0070^{* *}$ & 0.0148 & $-0.0060^{*}$ & $0.0208^{*}$ \\
$* * * \mathrm{p}<0.01, * * \mathrm{p}<0.05, * \mathrm{p}<0.10$ From Table 3. & $0.0050^{*}$ & -0.0041 & $0.0050^{*}$ & -0.0020 \\
\hline
\end{tabular}

Using the results for foreign aid per capita, for the regression that includes fixed effects, the estimated multipliers are negative for all the types of foreign aid - though only significant for the economic infrastructure-except for the social infrastructure aid. The positive 0.0208 multiplier for social infrastructure implies that if the goal of the policymaker was to permanently increase the recipient countries economic growth, they would need to increase the foreign aid given per person by about $\$ 48.19$. For the other types of foreign aid policymakers would want to decrease the amount of foreign aid that is being given. This should not be that controversial of a result because the other types of foreign aid do not have as direct of a connection with factors that are consistent with a neoclassical growth model. The goal of the types of foreign aid appears be separate from economic growth.

We could extend the generalization of equation (1), following Karras (2006) but also including a control for human capital which has been shown to be an important predictor of steady state effects (Mankiw, Romer, Weil 1992) —as follows:

Growth $_{i, t}=w_{i}+v_{t}+C(L)$ Growth $_{i, t-1}+b_{\text {aid }} * \operatorname{aid}_{i, t}+B_{\text {aid }}(L) \Delta a i d_{i, t}+b_{H C} * H C_{i, t}+B_{H C}(L) \Delta H C_{i, t}+b_{P o p} * P_{o p}{ }_{i, t}+$ $B_{\text {Pop }}(L)$ Pop $_{i, t}+b_{I} * I_{i, t}+B_{I}(L) \Delta I_{i, t}+b_{G} * G_{i, t}+B_{G}(L) \Delta G_{i, t}+u_{i, t}$

But because of the data limitations for the foreign aid by type we lack the degrees of freedom.

\section{CONCLUSION}

This paper explored the relationship between what sector the foreign aid is given and per capita economic growth for a panel of 69 developing countries 2002 to 2017. The paper uses a cross-section analysis for comparison reasons using traditional neoclassical variables that have been shown to have steady state effects-human capital accumulation, investment, population growth, and government expenditure. Additionally, we consider foreign aid that can be donated in one of three sectors - economic infrastructure, social infrastructure, and production sector - measured as either a percentage of GDP or by per capita. By not relying on a cross-sectional methodology, we are able to utilize both time and country specific fixed effects. These fixed effects are found to improve the fit of the model. 
The findings of the paper suggest that if a policymaker's goal is only to increase economic growth, then they should focus on aid towards the social infrastructure and not economic or production sectors. This analysis does not mean that there could not be other reasons to be donating into those other sectors, but they do not appear to be positively correlated with economic growth. Regarding money that is given towards social infrastructure the results suggest if the donor policymaker wanted to increase the developing countries economic growth by $1 \%$, they would need to increase the foreign aid given per person by about $\$ 48.19$.

\section{REFERENCES}

Batbold, B. (2017). Foreign Aid Effectiveness: What Type of Spending Matters for What Outcome. Thesis. Retrieved from https://hdl.handle.net/10027/22001

Boone, P. (1996). Politics and the Effectiveness of Foreign Aid. European Economic Review, 40, 289 329.

Brautigam, D.A., \& Knack, S. (2004). Foreign Aid, Institutions, and Governance in Sub-Saharan Africa. Economic Development and Cultural Change, 13, 255-285.

Burnside, C., \& Dollar, D. (2000). Aid, Policies, and Growth. The American Economic Review, 90, 847868.

Dalgaard, C., Hansen, H., \& Tarp, F. (2004). On the Empirics of Foreign Aid and Growth. Economic Journal, 114, F191-F216.

Dowling, M., \& Hiemenz, U. (1982). Aid, Savings, and Growth in the Asian Region. Economic Office Report Series 3, Asian Development Bank: Manila.

Easterly, W. (2006). The White Man's Burden: Why the West's Efforts to Aid the Rest Have Done So Much Ill and So Little Good. The Penguin Press HC.

Easterly, W., Levine, R., \& Roodman, D. (2004). New Data, New Doubts A Comment on Burnside and Dollar's “Aid, Policies, and Growth. The American Economic Review, 94(3), 774-780.

Fennstra, R., Inklaar, R., \& Timmer. (2015). The Next Generation of the Penn World Table. American Economic Review, 105(10), 3150-3182. Retrieved from www.ggdc.net/pwt

Gupta, K.L., \& Islam, M.A. (1983). Foreign Capital, Savings and Growth-An International Cross Section Study. Reidel Publishing Company: Dordrecht.

Hansen, H., \& Tarp, F. (2000). Aid Effectiveness Disputed. Journal of International Development, 12(3), 375-98.

Jones, C.I. (1995). Time Series Tests of Endogenous Growth Models. Quarterly Journal of Economics, $110,495-525$.

Karras, G. (2006). Foreign Aid and the Long-Run Economic Growth. Journal of International Development, 18, 15-28.

Larsen, N. (2016a). Nonlinearity in the Efficacy of Foreign Aid and Evidence of Poverty Traps. Journal of Developing Areas, 50(3), 69-92.

Larsen, N. (2016b). Nonlinearity in the Efficacy of Foreign Aid on Growth. Journal of Applied Business and Economics, 18(5), 23-41.

Larsen, N. (2020). Long Run Effects of Foreign Aid on Economic Growth. Journal of Applied Business and Economics, 22(13), 184-193.

Mankiw, N.G., Romer, D., \& Weil, D.N. (1992). A Contribution to the Empirics of Economic Growth. Quarterly Journal of Economics, 107(2), 407-437.

Obstfield, M. (1999). Foreign Resource Inflows, Saving and Growth. In K. Schmidt-Hebbel \& L. Serven (Eds.), The Economics of Saving and Growth: Theory, Evidence and Implications for Policy (pp. 107-146). Cambridge, New York.

Papanek, G.F. (1972). The Effect of Aid and Other Resource Transfers on Savings and Growth in Less Developed Countries. Economic Journal, 82(327), 935-950.

Sachs, J. (2004). Ending Africa's Poverty Trap. Brookings Papers on Economic Activity, 35, 117-240. 
Sachs, J. (2005). The End of Poverty: Economic Possibilities for Our Time. The Penguin Press: New York, NY.

Temple, J.R.W. (2010). Aid and Conditionality. Handbook of Development Economics, 5, 4415-4523.

\section{STATISTICAL APPENDIX}

TABLE 1

DESCRIPTIVE STATISTICS FOR COUNTRIES THAT RECEIVED FOREIGN AID

\begin{tabular}{lrrrrr} 
Variable & Obs & Mean & Std. Dev. & Min & Max \\
\hline Growth & 69 & 0.035 & 0.021 & -0.013 & 0.085 \\
Ln(Initial GDP/N) & 69 & 8.107 & 0.869 & 6.195 & 9.562 \\
Ln $($ Final GDP/N) & 69 & 8.667 & 0.950 & 6.589 & 10.191 \\
Ln(HC) & 69 & 0.720 & 0.249 & 0.155 & 1.181 \\
Ln(Pop) & 69 & -4.026 & 0.668 & -6.023 & -2.953 \\
Ln(I) & 69 & -1.567 & 0.332 & -2.346 & -0.844 \\
Ln(G) & 69 & -1.900 & 0.424 & -4.076 & -1.192 \\
Ln(Aid/N) & 69 & 3.099 & 0.935 & 0.379 & 4.936 \\
Ln(Aid/GDP) & 69 & -5.352 & 1.451 & -8.764 & -3.219 \\
Ln(EconAid/N) & 69 & 0.661 & 1.072 & -2.508 & 3.318 \\
Ln(EconAid/GDP) & 69 & -7.814 & 1.212 & -12.103 & -5.666 \\
Ln(SocialAid/N) & 69 & 2.167 & 0.999 & -0.460 & 4.055 \\
Ln(SocialAid/GDP) & 69 & -6.306 & 1.467 & -9.443 & -4.072 \\
Ln(ProdAid/N) & 69 & 0.283 & 1.098 & -2.303 & 2.126 \\
Ln(ProdAid/GDP) & 69 & -8.183 & 1.552 & -11.774 & -5.767 \\
\hline
\end{tabular}

TABLE 2

LIST OF CRS PURPOSE CODES AND VOLUNTARY BUDGET IDENTIFIER CODES

100-Social Infrastructure and Services

\begin{tabular}{|r|l|}
\hline 110 & Education \\
\hline 111 & Education, Level Unspecified \\
\hline 112 & Basic Education \\
\hline 113 & Secondary Education \\
\hline 114 & Post-Secondary Education \\
\hline 120 & Health \\
\hline 121 & Health, General \\
\hline 122 & Basic Health \\
\hline 123 & Non-communicable diseases (NCDs) \\
\hline 130 & Population Policies/Programmes \& Reproductive Health \\
\hline 140 & Water Supply \& Sanitation \\
\hline 150 & Government \& Civil Society \\
\hline
\end{tabular}




\begin{tabular}{|l|l|}
\hline 151 & Government \& Civil Society-general \\
\hline 152 & Conflict, Peace \& Security \\
\hline 160 & Other Social Infrastructure \& Services \\
\hline \multicolumn{2}{|c|}{} \\
\hline 210 & Transport \& Storage \\
\hline 220 & Communications \\
\hline 230 & Energy \\
\hline 231 & Energy Policy \\
\hline 232 & Energy generation, renewable sources \\
\hline 233 & Energy generation, non-renewable sources \\
\hline 234 & Hybrid energy plants \\
\hline 235 & Nuclear energy plants \\
\hline 236 & Energy distribution \\
\hline 240 & Banking \& Financial Services \\
\hline 250 & Business \& Other Services \\
\hline & \\
\hline 310 & Agriculture, Forestry, Fishing \\
\hline 311 & Agriculture \\
\hline 312 & Forestry \\
\hline 313 & Fishing \\
\hline 320 & Industry, Mining, Construction \\
\hline 321 & Industry \\
\hline 322 & Mineral Resources \& Mining \\
\hline 323 & Construction \\
\hline 330 & Trade Policies \& Regulations \\
\hline 331 & Trade Policies \& Regulations \\
\hline 332 & Tourism \\
\hline
\end{tabular}

Source: http://www.oecd.org/dac/stats/purposecodessectorclassification.htm 